\title{
Military Cold Injury During the War in The Falkland Islands 1982: An Evaluation of Possible Risk Factors
}

\author{
Lt Col R P Craig \\ MB, BS, FRCS, RAMC \\ Queen Elizabeth Military Hospital, Woolwich
}

SUMMARY: Throughout the history of war, there have been many instances when the cold has ravaged armies more effectively than their enemies. Delineated risk factors are restricted to negro origins, previous cod injury, moderate but not heavy cigarette smoking and the possession of blood group 0 . No attention has been directed to the possibility that abnormal blood constituents could feasibly predispose to the development of local cold injury. This study considers this possibility and investigates the potential contribution of certain components of the circulating blood which might do so.

Three groups of soldiers from two of the battalions who served during the war in the Falkland Islands in 1982 were investigated. The risk factors which were sought included the presence or absence of asymptomatic cryoglobulinaemia, abnormal total protein, albumin, individual gamma globulin or complement C3 or C4 levels, plasma hyperviscosity or evidence of chronic alcoholism manifesting as high haemoglobin, PCV, RBC, MCV or gamma glutamyl transpeptidase (GGT).

No cases of cryoglobulinaemia were isolated and there was no haematological evidence to suggest that any of those men who had developed cold injury, one year before this study was performed, had abnormal circulating proteins, plasma hyperviscosity or indicators of alcohol abuse. Individual blood groups were not incriminated as a predisposing factor although the small numbers of negroes in this series fared badly.

Although this investigation has excluded a range of potential risk factors which could contribute to the development of cold injury, the problem persists.

Two areas of further study are needed: the first involves research into the production of better protective clothing in the form of effective cold weather boots and gloves and the second requires the delineation or those dietary and ethnic factors which allow certain communities to adapt successfully to the cold. $A$ revieu of the literature in this latter area is presented.

\section{Introduction}

Local cold injury may greatly reduce effective combatant troops in war and can result in considerable morbidity during exercises in peacetime. Its significance and occurrence is underestimated and frequently under-diagnosed. Until the Falklands War of 1982 the last occasion in which British servicemen fought in a cold climate was in Korea and the remaining medically qualified veterans of that conflict have nearly all retired.

There are historical instances in which the cold has inflicted more battle casualties than the enemy. Larrey $^{1}$ reported the loss of 11650 out of 12000 men of the 12th division of Napoleon's Grand Army during the Russian Campaign and Hitler's advance into, and subsequent retreat from, the USSR during World War II resulted in both sides losing catastrophic numbers of men from the cold ${ }^{2}$. The British Army documented 115361 cases of frostbite and trench foot in the official records of World War I but the majority of these occurred early in the conflict. With the introduction of duckboards, the issue of dry socks and strictly imposed foot and hygiene discipline the incidence dropped during the later years of the campaign ${ }^{3}$. The influence of these measures in combating cold injury was again manifest during World War II in North West Europe where British casualties were much lower than the 91000 suffered by the United States Army of whom some $87 \%$ were infanteers. There were times during the winter of 1944-1945 when the cold resulted in up to one-third of American battle casualties, ${ }^{4,5}$.

No accurate figures for the number of British and Argentinian troops who fought in the Falklands and sustained cold injury are available although symptoms were recorded in $28.5 \%$ of 3 Para and $20-30 \%$ of 2 Scots Guards ${ }^{6}$.

Non-freezing and freezing cold injury not only reduces fighting capability in war but also occurs sporadically in the United Kingdom and in North West Europe amongst soldiers either on exercises or as a result of sleeping rough whilst intoxicated.

Any blood constituent which would impair flow at reduced temperature is likely to predispose to damage in a cold environment. Cryproteins are known to do so $^{7}$.

The digital necrosis seen in patients with cryo- 
globulinaemia is clinically indistinguishable from that produced by freezing and this appearance raised the possibility that there might be a group of otherwise asymptomatic individuals who had small quantities of cryoglobulins circulating in their blood which might predispose them to developing cold injury. The further possibility that there could be a number of Servicemen who were polycythaemic and hyperviscid due to the effects of chronic alcohol ingestion could explain why some but not all personnel who served in the Falklands campaign sustained cold injury whilst others subjected to similar conditions did not do so.

This study examines these possibilities by comparing venous blood obtained from British Servicemen who had clinical cold injury during the campaign with a similar group who experienced the same environmental conditions but did not do so and a further group who did not participate.

\section{Subjects and Methods}

Six groups of soldiers, three from the 3rd Battalion, The Parachute Regiment and three from the 2nd Battalion, Scots Guards were studied. The first two groups (A) consisted of men from these battalions who were diagnosed as having sustained cold injury in the Falklands. Confirmation of this diagnosis has been substantiated in most cases by objective measurement of impaired nerve conduction and by abnormal vasomotor response to a cold stimulus observed by strain-gauge plethysmography, (McCaig 1983) ${ }^{8}$. The second two groups (B) consisted of men of similar age who had gone to the Falklands but who did not sustain injury despite being subjected to an identical environment. Selection of these subjects was made by the sub-unit commanders who had led them during the war. The third group (C) consisted of a similar number of soldiers who did not go to the Falklands and who had not previously suffered the effects of cold elsewhere in the world.

All personnel gave informed written consent for venipuncture, which was performed two to three hours after a midday meal. Consent forms were numbered serially and allocated randomly. Thus the sampling and analysis was performed blind and the groupings constructed after the results were obtained from lists provided by the units.

Samples of $20 \mathrm{ml}$ venous blood were withdrawn from the antecubital fossa using a venous tourniquet into syringes and needles warmed to $37^{\circ} \mathrm{C} .10 \mathrm{ml}$ of this blood was immediately transferred to EDTA lined bottles previously warmed to $37^{\circ} \mathrm{C}$ and replaced in a warmer at the same temperature. The warmed specimens were centrifuged at $37^{\circ} \mathrm{C}$ for 10 minutes at $1000 \mathrm{rpm}$ followed by 15 minutes at
2000 rpm. Thereafter, the supernatant plasma was collected into plain bottles at room temperature and transferred for cryoglobulin, total protein, albumin, IgC, IgA, IgM, complement $\mathrm{C} 3$ and $\mathrm{C} 4$ estimation. These plasma samples were divided into three $\Rightarrow$ aliquots, one placed at $4{ }^{\circ} \mathrm{C}$, one at $37^{\circ} \mathrm{C}$ and thes? third retained at room temperature. Regular inspec-O tion was carried out for 72 hours but no cryo- $\bar{E}$ proteins were observed. Immunoglobulin (IgG, IgA,,$\overline{\frac{D}{}}$ IgM, C3 and C4) levels were estimated by immuno- $\triangle$ nephalometry on a Disc 120 laser nephalometer (Hyland Laboratories, USA) using goat antisera to IgG, C3 \& C4 (Atlantic Antibodies, USA), IgA, IgM (ICL, Scientific, USA). Total protein and $\vec{\omega}$ albumin levels were obtained by standard laboratory techniques.

The other specimens were analysed by routine methods on a Coulter S Senior, (Coulter Electronics, $\frac{\dot{ }}{\omega}$ Linton, Beds.) for haemoglobin, packed cell volume,, red cell count and MCV. Plasma viscosity was N determined on a Harkness Coulter Viscometer ${ }^{9}$ a gamma glutamyl transpeptidase levels were estimatedo by an automated method using the technique of $f_{-}^{\supset}$ Szasz $^{10}$ on a Coulter Kem-o-mat autoanalyser.

Reference ranges were: total protein, $\left(55-79 \mathrm{~g} / \mathrm{P}, \frac{\mathrm{g}}{2}\right.$ albumin, (30-42g/1), IgG, (5.4-16.1g/1), IgA, (0马) $3.4 \mathrm{~g} / \mathrm{I})$, IgM $(0.5-2 \mathrm{~g} / 1), \mathrm{C} 3,(0.7-1.7 \mathrm{~g} / 1), \mathrm{C} 4,(0 \mathrm{~d}-$ $0.7 \mathrm{~g} / 1)$, plasma viscosity $(1.5-1.72 \mathrm{cp})$ and $\mathrm{GG}_{\widehat{C}}, \vec{\infty}$ (6-28iu/1).

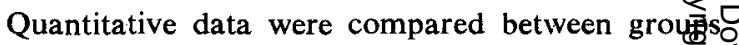
using an unpaired test and blood group data were analysed using a Chi Squared test with Yates cor-o rection where applicable.

\section{Results}

Although the mean ages of the groups in $2 \mathrm{SG} \supset$ were higher than those in 3 PARA, no statisticato differences were evident. They are shown on Table 1.3

\section{Table I}

Subjects Studied

\begin{tabular}{cc}
\hline Number & Age (Yrs) \\
\hline 3 Para &
\end{tabular}

3 Para

Group A

Group B 15

Group C 16

$22.2 \pm 2.33 * \frac{1}{0}$

$21.4 \pm 2.10$

2 SG

Group A 16

Group B 16

Group C 16

$20.3 \pm 2.55$ 윽

$* \pm 1 \mathrm{SD}$ 
Information was obtained from the RMO's of the two battalions ${ }^{6}$ on the distribution of blood groups as was data on those soldiers who were studied. Tables II(a) and II(b) show these distributions.

The variation in the proportions of blood group genotypes between the two battalions reflects regional differences in the distributions of blood groups. In this small series no protection due to the carriage

Table II (a)

\begin{tabular}{lcccc}
\hline $\begin{array}{l}\text { Blood } \\
\text { Groups }\end{array}$ & A & B & O & AB \\
\hline 3 Para & & & & \\
Rh Pos. & 178 & 41 & 183 & 25 \\
Rh. Neg. & 30 & 0 & 51 & 0 \\
\hline Totals & $208(40.9 \%)$ & $41(8.1 \%)$ & $234(46.0 \%)$ & $25(4.9 \%)$ \\
\hline 2 SG & & & & \\
Rh Pos. & 165 & 52 & 263 & 18 \\
Rh. Neg. & 17 & 9 & 19 & 2 \\
\hline Totals & $182(33.3 \%)$ & $61(11.2 \%)$ & $282(51.7 \%)$ & $20(3.64 \%)$ \\
\hline
\end{tabular}

Table II (b)

$A B O$ and Rhesus Distribution between the Study Groups

\begin{tabular}{lrrrrrr}
\hline & A & B & O & AB & Rh + & Rh- \\
\hline 3 Para & & & & & & \\
Group A & 8 & 1 & 4 & 1 & 10 & 4 \\
Group B & 6 & 1 & 8 & 0 & 13 & 2 \\
Group C & 7 & 0 & 8 & 1 & 12 & 4 \\
2 SG & & & & & & \\
Group A & 5 & 0 & 9 & 2 & 15 & 1 \\
Group B & 4 & 2 & 10 & 0 & 16 & 0 \\
Group C & 5 & 2 & 9 & 0 & 14 & 2 \\
\hline
\end{tabular}

of blood group A was found nor were there any $z$ statistical indicators suggesting an increased tendency $\stackrel{\varnothing}{\varrho}$ to suffer cold injury in holders of blood group 0 . $ᄋ$

The results of haemoglobin, packed cell volume, red cell count and mean corpuscular volume are delineated in Table III.

Haemoglobin levels were found to be higher in Group C of 2 SG when compared with Group $C$ of 2 Para $(P<.05)$ but MCV levels were comporable $\frac{\bar{N}}{7}$ between all groups despite being numerically higher $\mathbb{\Phi}$ in 2 SG.

Table IV gives the results of plasma viscosity and $\overrightarrow{0}$ gamma glutamyl transpeptidase (GGT) levels. Once again these figures were similar, the GGT levels in $\vec{\omega}$ 2 SG being higher than those in 3 PARA. The? levels in Group B of 3 PARA were higher than Group C $(\mathrm{P}<.05)$.

Finally, Table $V$ shows the results of total protein, $\vec{\omega}$ albumin, IgG, IgA, IgM, complement $\mathrm{C} 3$ and $\mathrm{C} 4$. No statistical differences were evident.

Both total protein and albumin levels were at of above the upper limit of normal for the laboratory 의 reference range which is thought to reflect the excellent state of nutrition and fitness seen in these soldiers.

Cryoglobulins were not found in any of the soldiers who were studied.

Six soldiers had GGT levels in excess of 50iu/ $\$$ In four of these the plasma viscosity was raised bu $\mathrm{MCV}$ was above $95 \mathrm{fl}$ in only one and $\mathrm{C} 3>1.70 \mathrm{~g} \overline{9}$ in three. There were eight men with raised $\mathrm{MCV}$ in whom only one had an elevated GGT but four had raised plasma viscosity and C3. Plasma viscosities higher than $1.72 \mathrm{cp}$ were measured in 20 individuals. In this group two had an elevated MCV, four a raised GGT and five a raised $\mathrm{C} 3$.

It can be concluded that the incidence of alcohol

Table III

Haematology Results \pm ISD

\begin{tabular}{|c|c|c|c|c|}
\hline & $\mathrm{Hb} \quad \mathrm{g} / \mathbf{l}$ & PCV & $\begin{array}{l}\text { Red Cell Count } \\
\left(10^{-12} / 1\right)\end{array}$ & $\begin{array}{l}\operatorname{MCV} \\
\text { (fl) }\end{array}$ \\
\hline \multicolumn{5}{|l|}{3 Para } \\
\hline Group A $(n=14)$ & $15.02 \pm 0.92$ & $45.50 \pm 2.34$ & $4.885 \pm 0.357$ & $89.14 \pm 3.11$ \\
\hline Group B $(n=15)$ & $15.47 \pm 1.16$ & $46.09 \pm 3.17$ & $4.989 \pm 0.357$ & $88.50 \pm 3.34$ \\
\hline Group $C(n=16)$ & $14.91 \pm 1.04 \dagger$ & $45.38 \pm 3.00$ & $4.912 \pm 0.351$ & $88.56 \pm 2.52$ \\
\hline \multicolumn{5}{|l|}{2 Scots Guards } \\
\hline Group A $(n=16)$ & $16.10 \pm 0.88$ & $47.54 \pm 2.72$ & $5.033 \pm 0.241$ & $92.13 \pm 4.00$ \\
\hline Group B $(n=16)$ & $15.50 \pm 0.71$ & $45.83 \pm 0.47$ & $4.893 \pm 0.201$ & $91.30 \pm 2.55$ \\
\hline Group C $(n=16)$ & $16.18 \pm 1.02 \dagger$ & $47.74 \pm 3.02$ & $4.998 \pm 0.290$ & $93.25 \pm 4.16$ \\
\hline
\end{tabular}


Table IV

Plasma Viscosity (c p) and Gamma Glutamyl

Tranpeptidase GGT (IU/1) Results \pm ISD

Viscosity (cp) Gamma GT (IU/1)

\begin{tabular}{lll}
\hline 3 Para & & \\
Group A $(n=14)$ & $1.688 \pm 0.121$ & $16.93 \pm 8.84$ \\
Group B $(n=15)$ & $1.682 \pm 0.079$ & $23.00 \pm 10.78^{*}$ \\
Group C $(n=16)$ & $1.655 \pm 0.057$ & $12.75 \pm 4.88^{\star}$ \\
2 Scots Guards & & \\
Group A $(n=16)$ & $1.663 \pm 0.067$ & $31.19 \pm 35.73$ \\
Group B $(n=16)$ & $1.644 \pm 0.087$ & $27.19 \pm 23.75$ \\
Group C $(n=16)$ & $1.691 \pm 0.092$ & $26.5 \pm 11.55$ \\
\hline
\end{tabular}

${ }^{*} \mathrm{P} .05$ adapted individuals would cause damage. This $\underset{\varnothing}{\$}$ capacity would appear to be related to maintenance $\stackrel{\odot}{\not}$ of higher skin temperatures and has been reported $?$ in Arctic Indians ${ }^{14}$, Alakaluf Indians ${ }^{15}$, and in Arctic Eskimos $^{16}$. It remains unclear as to what the? aetiology of this adaptive response can be ascribed $\vec{F}$ although an Eskimo's basal metabolic rate is higher than a Caucasian of comparable surface area and $\frac{}{5}$ lean body mass ${ }^{17}$. By inference, this excess energy $\frac{\bar{\sigma}}{\bar{p}}$ expenditure could be taking place in the vasodilated $\overrightarrow{\widetilde{\Phi}}$ extremities of these peoples. Little et al $^{18}$ (1971) tested skin temperature responses in groups of $\omega$ young and adult Peruvian Indians. One group was $\overrightarrow{0}$ compared with adult American and British Cauca- $-\overrightarrow{-}$ sians. The adult Indians, regardless of their place of $\vec{\omega}$

Table $\mathbf{V}$

Protein Results $(\mathrm{g} / \mathbf{1} \pm \mathbf{1 S D})$

Total Protein Albumin

$(\mathrm{g} / \mathrm{l})$

$(\mathrm{g} / \mathrm{l})$

$\operatorname{IgG}(g / 1)$

$\lg \mathrm{A}(\mathrm{g} / \mathrm{l})$

$\operatorname{IgM}(\mathrm{g} / \mathrm{l})$

C3 $(g / 1)$

$\mathrm{C} 4(\mathrm{~g} / \mathrm{l})$

3 Para

Group A $\quad(n=14) 84.57 \pm 3.78$

$44.86 \pm 3.25$

$11.71 \pm 0.01$

$2.40 \pm 0.96$

$1.49 \pm 0.52$

$1.25 \pm 0.24$

$0.45 \pm 0.24$

Group B

$(n=15) 84.2 \pm 4.39$

$44.0 \pm 1.89$

$12.08 \pm 1.81$

$2.30 \pm 0.83$

$1.55 \pm 0.69$

$1.33 \pm 0.23$

$0.49 \pm 0.41$

Group C $\quad(n=16) 81.19 \pm 4.12$

$42.25 \pm 3.11$

$11.25 \pm 1.47$

$2.55 \pm 0.56$

$1.35 \pm 0.63$

$1.38 \pm 0.29$

$0.39+0.15$

\section{Scots Guards}

Group A $\quad(n=16) 86.88 \pm 4.22$

$44.06 \pm 3.43$

$12.51 \pm 1.85$

$1.98 \pm 0.58$

$1.72 \pm 0.54$

$1.43 \pm 0.30$

$0.59 \pm 0.42$

Group B $\quad(n=16) 84.31 \pm 4.96$

$44.00 \pm 3.18$

$11.84 \pm 2.00$

$1.63 \pm 0.51$

$1.76 \pm 0.63$

$1.34 \pm 0.21$

$0.61 \pm 0.41$

Group C $\quad(n=16) 86.75 \pm 3.82$

$42.44 \pm 1.86$

$13.09 \pm 1.63$

$1.92 \pm 0.79$

$1.74 \pm 0.54$

$1.42 \pm 0.18$

$0.52 \pm 0.19$

abuse based upon haematological and biochemical markers in this series of 93 soldiers was very low one year after 61 of them had served in the South Atlantic. In only one individual were all markers positive and although he was in the affected group of $2 \mathrm{SG}$ there is no evidence on these results to suggest that alcohol abuse played any significant part in the development of cold injury in the Falklands.

There were no negroes in 2 SG but all four of those in 3 PARA suffered cold injury.

\section{Discussion}

There are several factors which may cause an individual to be more susceptible to local cold injury. Caucasians fare better in a cold environment than negroes who have a 2.8 to six fold increased likelihood of developing symptoms, although the reasons for this difference have yet to be defined ${ }^{11,12,13}$. Animals or man either adapt to their environment or perish. There are numerous recorded examples of man's ability to avoid cold induced injury despite exposure, which in non- dwelling, maintained higher skin temperatures after cold exposure than the whites implying a strong $\mathbb{Q}$ genetic effect, but they also maintained higher tem- $\vec{\overrightarrow{ }}$ peratures than the Indian children which would sug- $\frac{0}{3}$ gest a degree of adaptation during life. The influence of genetic mixing between Indians and Caucasians was studied by measuring the rate at which cold induced vaso-dilation (CIVD) occurred after handimmersion at $5^{\circ} \mathrm{C}$ in two groups of Canadian Algonkian Indians from two villages ${ }^{19}$. They concluded that the onset of CIVD occurred later in the Indians with greater Caucasian admixture.

In addition to these genetic factors there is a real possibility that diet may contribute to adaptation to environmental cold. Laursen ${ }^{17}$ (1983) has noted that the capacity of Alaskan Eskimos to cope with freezing conditions appears to be lost if they trans- $\frac{}{\partial}$ fer their diet to that of Westerners and stop con- $\frac{D}{5}$ suming seal blubber and fish. Sinclair ${ }^{20}$ (1953) failed to find any cholesterol deposition in the corneas of $N$ Eskimos on a traditional diet which contains the highest known proportion of dietary fat. Coronary 0 heart disease is not observed in these people ${ }^{21}$. Fish $\omega$ 
and blubber fat is rich in linolenic acid as is the dietary fat consumed by the Japanese in whom atherosclerosis is also rare. $\mathrm{He}$ extended his experiments by joining a community of long living Eskimos in Greenland in 1976 and subsequently consumed seal and fish as his sole nourishment for 100 days $^{22}$. This resulted in extension of his bleeding time from four minutes to in excess of 50 minutes and greatly decreased his platelet aggregation. He postulated that this effect was caused by the high intake of linolenic acids resulting in the production of prostacyclin, (PGI3) and thromboxane (TXA3) rather than PGI2 or TXA2 which are derived from linoleic acid. Whereas PGI2 and PGI3 both deaggregate platelets, TXA2 promotes thrombosis whilst TXA3 has little or no effect upon platelets. These interesting findings do suggest that diet may be an important contributor to the circulation of blood in the extremities of Eskimos who consume traditional food and may reduce the likelihood of intravascular thrombosis during periods of impaired flow and hyperviscosity in a cold environment ${ }^{20,22}$.

Rather more difficult to explain on either genetic or dietary grounds is the capacity to adapt to occupations involving the handling of cold objects or immersion of feet in cold water. Examples include Gaspe fishermen ${ }^{23}$, fish filleters ${ }^{24}$, and Canadian lumberjacks ${ }^{25}$ whose feet remain immersed and cold for long periods without deleterious effect. A fish diet in the first instances and active movement and exercise in all examples may result in improved circulation in these cases along with an acquired capacity to vasodilate.

Raynaud's phenomenon whether it be idiopathic or secondary to peripheral vascular disease, thromboangiitis obliterans, vibration injury, previous cold injury or to mixed connective tissue disease greatly increase predisposition to the effects of cold ${ }^{26}$.

Other factors which have been delineated include moderate but not heavy cigarette smoking, fatigue, ethanol consumption, hyperhidrosis, reduced lean body mass, blood group $\mathrm{O}$ individuals, inadequate clothing and footwear, hygiene, rank and motivation $^{3,11,25}$.

With the exception of $\mathrm{ABO}$ blood groupings no attention has been paid in the literature to the possibility that the physical properties or composition of the blood itself could predispose to the development of cold injury. Nor is it clear whether the pathological effects of the cold upon the extremities is the direct result of intravascular thrombosis alone or due to an inflammatory response with endothelial damage and vascular destruction in addition. Eady et $\mathbf{a l}^{27}$, (1981) in a study of cold induced urticaria and vasculitis, demonstrated the appearance of complement $\mathrm{C} 3$ in dermal blood vessels following a cold stimulus which preceded deposition of fibrin and immunoglobulin within the vessel wall and was associated with mast cell degranulation. There was later perivascular inflitration by inflammatory cells and later still vascular endothelial disruption. Controls showed no such response.

Cryoglobulinaemia has been recognised since $1933^{28}$, and the conditions in which it has been observed include myelomatosis, lymphoma, mixed connective tissue disorders including rheumatoid arthritis, systemic lupus erythematosis, Sjogren's disease, cirrhosis, Crohn's disease and disseminated malignancy ${ }^{29-33}$. There were a number of cases reported above in whom the aetiology for cryoglobulinaemia was unknown and they were described as being essential or idiopathic. Mcgrath and Penny? (1978) demonstrated greatly increased blood and plasma viscosity in cases of cryoglobulinaemia with an associated increased red cell aggregation on cool ing at low shear rates. They suggested that this finding explained at least in part the localisation on damage to the skin in those peripheral tissues of the extremities most exposed to cold.

Dehydration due to the combined effects excessive sweating within the clothing required a cold environment along with a reduced intake o water also results in hyperviscosity ${ }^{34}$. Chroni alcohol abuse is associated with a raised MCV an gamma glutamyl transpeptidase, $(\mathrm{GGT})^{35-38}$.

This study has investigated several component of the circulating blood in soldiers who served in the Falklands Campaign of 1982 and has effectively excluded many of them as being aetiological factors in the development of non-freezing cold injury. Thus the reasons why some and not all individuals who are subjected to similar adverse environmental circumstances develop symptoms remains unanswered.

The study was performed one year after the event. As no cases of cryoglobulinaemia were found in any of the soldiers in any of the three groups who were studied, it would seem most unlikely that small groups of individuals with asymptomatic cryoglobulinaemia exist. Whereas it is recognised that epinephrine release produces distal vasoconstriction in association with fear, the concommitant production of cryoglobulins in these circumstances has not been investigated. Perhaps venous sampling of parachutists prior to their first jump might confirm or refute this possibility.

It is known that the circulation in the fingers can be reduced to $3 \%$ of control levels following immersion in water at $13^{\circ} \mathrm{C}$ for two hours ${ }^{39}$ or to zero at temperatures between $0^{\circ} \mathrm{C}$ and $8^{\circ} \mathrm{C}^{40}$. Associated with this diminution of flow is a tendency 
to sludging and microvascular occlusion. Thus, polycythaemia or hyperviscosity would tend to accentuate this phenomenon ${ }^{41}$. Although high haemoglobin levels have been recorded in chronic alcoholics ${ }^{42}$ it is still disputed whether this is entirely due to the alcohol or whether it derives from the stimulus produced by consistently high levels of carbon monoxide found in heavy smokers who also drink. The possibility that certain soldiers might be found to have biochemical or haematological evidence of chronic alcohol abuse was explored bearing in mind that one year had elapsed between the exposure to cold and also that alcohol intake was restricted to two cans of beer per day during the sea voyage between Ascension Island and the Falklands. This restriction, however, would not necessarily permit a considerably greater intake by alcohol abusers who could have increased their consumption by certain forms of barter.

The concept of hyperviscosity and an increased tendency to sludging associated with a high haematocrit and polycythaemia may contribute to the high proportions of chronic alcoholics who form the bulk of most of the civilian series of frostbite ${ }^{43-45}$. More likely is that these cases occur due to acute inebriation causing them to sleep rough in cold weather. It is nonetheless worthwhile to consider chronic alcoholism particularly in troops who are to be exposed to the extremes of cold either on exercise in peacetime or in war.

The tendency for negroes to be more susceptible to the cold than Caucasians was confirmed in this study albeit with small numbers.

The proportion of the population with Group A blood is higher in Scandinavia than in the rest of Europe and it has been postulated that this is associated with an evolutional capacity to withstand cold $^{4 \mathrm{e}}$. Group B blood becomes increasingly common through Eastern Europe and into Asia ${ }^{46}$. Group O American soldiers have been found to have a 1.8 times increased chance of cold injury during training in Alaska. Whereas 3 Para have a pattern of blood groups which is in close parallel with England despite drawing from all areas of the nation, the 2 SG who recruit $60 \%$ of their troops from north of the border had a pattern of distribution which is identical to that found in SW Scotland with a Group A proportion of only $33 \%$ and with $52 \%$ group $\mathrm{O}^{25}$. This would appear to reflect a Celtic rather than Scandinavian ancestry. There is no indication, however, to restrict soldiers' employment because of their blood genotypes.

Complement $\mathrm{C} 3$ and IgM deposition in the walls of dermal blood vessels has been shown to be an early finding in the development of vasculitis associ- ated with cold urticaria ${ }^{27}$. In this series, immuno- $\frac{3}{\infty}$


indistinguishable between groups and none of these $\bigcirc$ proteins have been shown to be of aetiological importance in the development of non-freezing cold injury.

It was not possible to obtain information on the smoking habits of the men from these two battalions $\frac{\bar{\sigma}}{\bar{N}}$ who served in the Falklands. Information from the $\frac{\bar{\sigma}}{\vec{D}}$ 93 who were investigated as regards smoking was $\stackrel{\mathbb{D}}{\unrhd}$ not sought. Previous work carried out in Alaska ${ }^{11,12,25}$, ڤ has revealed that light smokers (less than 20 per day) had a higher risk of sustaining frostbite than 9 non-smokers or heavy smokers (more than 20 per $\overrightarrow{\vec{\omega}}$ day).

\section{Conclusions}

The cold produced considerable morbidity and $\vec{\omega}$ loss of fighting strength during the Falklands Cam- i paign as it has on innumerable occasions throughout the history of war. This study has excluded somo o of the possible factors within the circulating bloof $ᄋ$ which might have predisposed to its development.

The following areas of research warrant furthe evaluation. Improvements in cold weather clothin and particularly foot and hand wear is a majoq priority. Further data on the microscopic, electro microscopic and biochemical nature of the effect of cold upon blood vessel walls, nerves and derma cells is required. The possible contribution of dit and specifically those rich in omega 3 poly? unsaturated fatty acids similar to that consumed by Eskimos who have successfully adapted to their environment needs investigation. Ways in which the prolonged bleeding time produced by this diet could be rapidly corrected in the event of wounding should be sought. Evaluation of vasodilator drugs as prophylactics might prove a worthwhile avenue for study.

Finally, standardisation and quantification of the effects of previous cold injury is required in order to assess prognosis, future employment standards and the possibility of improving late vasospastic symptoms by sympathectomy the value of which in the acute phases of frostbite remains questionable ${ }^{44,45}$.

\section{Acknowledgements}

The efficiency and co-operation of 2 SG and 3 PARA in providing soldiers for this study is greatly appreciated. Both the ABSD and John Boyd Laboratory gave inestimable help with venous sampling and analyses. Particular thanks are due ,

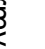


to Dr. Pamela Riches and the Protein Reference Laboratory at the Westminster Hospital for advice and for the cryoglobulin, protein and complement estimations.

This study was approved by AMS Research Executive Committee as Project No. 277.

\section{REFERENCES}

1 LARrey, D J. Memoirs of Baron Larrey, Surgeon in Chief to the Grand Armee. London: Henry Renshaw, 1861.

2 Churchill, W S. The Second World War. Vol 4: pp 637-638. London: Cassell, 1951.

3 Vaughn, P B. Local Cold Injury-Menace to Military Operations: A Review. Milit Med 1980; 145: 305 . 311.

4 Whayne, T F. Cold Injury in World War II: A Study in the Epidemiology of Trauma. US Government Printing Office, 1950.

5 Whayne, $T$ F and DeBakey, $M$ E. Cold Injury, Ground Type. US Government Printing Office, 1958.

6 Hands, P and Warsap, J. RMO/s 3 PARA, 2 SG. Personal Communications, 1983.

7 McGrath, M A and Penny, R. Blood Hyperviscosity in Cryoglobulinaemia: Temperature Sensitivity and Correlation with Skin Blood Flow. AJEBAK 1978; 56: 127-137.

8 McCalg, R. Personal Communication. 1983.

9 HaRkNess, The Viscosity of Human Blood Plasma: Its Measurement in Health and Disease. Biorheology 1971; 8: 171-193.

10 Szasz, G. A Kinetic Photometric Method for Serum Gamma-Glutamyl Transpeptidase. Clin Chem 1969; 5: 124-136.

11 Sumner, D S, Criblez, $T$ L and Doolittle, W $\mathrm{H}$. Host Factors in Human Frostbite. Milit Med 1974; 139: 454-461.

12 Millex, D and BJornson, D. R. An Investigation of Cold Injured Soldiers in Alaska. Milit Med 1962; 127: 247-252.

13 OrR, K D and Fainer, D C. Cold Injuries in Korea during 1950-1951. Medicine 1052; 31: 171220.

14 Elsner, R W, Nelms, J D and Irving, L. Circulation of Heat to the Hands of Arctic Indians. J Appl Physiol 1960; 15: 662-666.

15 Hammel, H T. Thermal and Mettabolic Responses of the Alakaluf Indians to Moderate Cold Exposure. WADD Tech Report No. 60-633; Wright Patterson AFB: Ohio 1960.

16 Brown, G M, and Page, J. The Effect of Chronic Exposure to Cold on Temperature and Blood Flow in the Hand. J Appl Physiol. 1952; 5: 211-227.

17 Laursen, G A. Whole Body Effects of Cold and Hypothermia. At Workshop on "Medical Operational Problems in a Cold Environment". Alverstoke, 1983.

18 Little, $M$ A et al. Population Differences and Developmental Changes in Extremity Temperature Responses to Cold Among Andean Indians. Hum Biol 1971; 43: 70-91.
19 Hurlich, M G and SteEgmann, A T. Hand Immer-市 sion in Cold Water at $5^{\circ} \mathrm{C}$ in Sub-Arctic Algonkian Indian Males from Two Villages: A European $\bigcirc$ Admixture Effect. Hum Biol 1979; 51: 255-278.

20 Sinclair, $\mathbf{H}$ M. The Diet of Canadian Indians and? Eskımos. Proc Nutr Soc 1953; 12: 69-80.


tion and Platelet Polyunsaturated Fatty Acids ino Eskimos. Lancet 1979; ii: 433-435.

22 Sinclair H M. Prevention of Coronary Hearto Disease: The Role of Essential Fatty Acids. Postgrad Med J 1980; 56: 579-584.

23 LeBlanc, J, Hildes, J $A$ and Heroux, O. Tol-œ̃ erance of Gaspe Fishermen to Cold Water. J Appl $\vec{\circ}$ Physiol 1960; 15: 1031-1034.

24 Nelms, J D and SOPER, D J G. Cold Vasodilation $\overrightarrow{\vec{H}}$ and Cold Acclimatization in the Hands of British Fish Filleters. J Appl Physiol 1962; 17: 444-448.

25 Hanson, H E and Goldman, R F. Cold Injury in Man: A Review of its Etiology and discussion of its Prediction. Milit Med 1969; 134: 1307-1316.

26 PorTer, J M et al. Evaluation and Management ${ }^{\omega}$ of Patients with Raynaud's Syndrome. Am J Surgo 1981; 142: 183-189.

27 EAdY, R A J et al. Cold Urticaria with Vasculit席: Report of a Case with Light and Electron Micre-o scopic, Immunofluorescence and Pharmacological Studies. Clin Exp Dermatol 1981; 6: 355-366. 굴

28 Wintrobe, M M and Buell, M V. Hyperprote aemia Associated with Multiple Myeloma. BAll Johns Hopkins Hosp 1933; 52: 156-165.

29 Meltzer, $M$ and Mranklin, E C. Cryoglobu过naemia-A Study of Twenty-Nine Patients. $A m_{O} J \overrightarrow{0}$ Med 1956; 40: 828-836.

30 Meltzer, $M$ et al. Cryoglobulinaemia A Clinioa and Laboratory Study. Am J Med 1966; 60: 83 856.

31 Aizawa, $Y$ et al. Vasculitis and Sjogren's Syn-⿳亠二口犬 drome with IgA-IgG Cryoglobulinaemia Terminat-్๊م ing in Immunoblastic Sarcoma. Am J Med 1979; $\mathbb{D}$ 67: $160-166$.

32 Lerner, A R, Barnum, C P and Watson, C J.ö Studies of Cryoglobulins: 11. The Spontaneous 3 Precipitation of Protein from Serum at $5{ }^{\circ} \mathrm{C}$ in Various Disease States. Am J Med Sci 1947; 214:0 416-421.

33 Mayer, L, Meyers, S and Janowitz, H D. Cryoproteinaemia in the Cutaneous Gangrene of Crohn's Disease: A Report of two Cases. J Clin Gastroenterol 1981; 3 (Suppl 1): 17-21.

34 Beeley, $\mathbf{J}$ M. Fluid Balance during Exercise in a Cold Environment. At Workshop on "Medical Operational Problems in a Cold Environment". Alverstoke, 1983.

35 BAXTER, $S$ et al. Laboratory Tests for Excessive Alcohol Consumption Evaluated in General Prac-O tice. $\mathrm{Br} J$ Alcohol and Alcoholism 1980; 15: 164166.

36 Morgan, M Y, Colman, J C and Sherlock, S. The Use of a Combination of Peripheral Markers foro Diagnosing Alcoholism and Monitoring for Continued Abuse. BrJ Alcohol and Alcoholism 1981; N 16: $167-177$.

37 CLARK, P M S and Kricka L J. Biochemical Tests ${ }_{N}$ For Alcohol Abuse. Br J Alcohol and Alcoholism 1981; 16: 11-26. 
38 Chick, J, Kreitman, N and Plant, M. Mean Cell Volume and Gamma Glutamyl-Transpeptidase as Markers of Drinking in Working Men. Lancet 1981; i: 1249-1251.

39 BARCRofT, $H$ and EDHOLM, O G. The Effect of Temperature on Blood Flow and Deep Temperature in the Human Forearm. J Physiol 1943; 102: 5-20.

40 Kramerk, K and Schulze, W. Die Kaltedilatation der Hautgefase. Arch $f d$ ges Physiol 1948; 250: 141-170.

41 LApp, N L and Juergens, J L. Subject Review: Frostbite. Mayo Clin Proc 1965; 40: 932-948.
42 Gravett, P J. 1984 (In Preparation).

43 Hermann, $G$ et al. The Problem of Frostbite in $\bigcirc$ Civilian Medical Practice. Surg Clin N Amer 1963:응 43: 519-536.

44 Isaacson, N $\mathbf{H}$ and Harrell, $J$ B. The Role of $\vec{\Rightarrow}$ Sympathectomy in the Treatment of Frostbite. $\stackrel{P}{+}$ Surgery 1953; 33: 810-816.

45 Golding, M R et al. The Role of Sympathectomy 흠 in Frostbite, with a Review. Surgery 1965; 57: $\frac{\bar{\omega}}{\sigma}$ 774-777.

46 Mourant, A E. The Distribution of the Human Blood Groups. Oxford: Blackwell, 1954.

\section{Journals/Publications Received}

The following Journals/Publications have been received and are available in the Royal Army Medical College Library.

\section{JOURNALS}

Annals of Clinical Research; Anais Do Instituto de Higiene E Medicina Tropical; Archives of Surgery; Annals Chirurgiae et Gynaecologiae; Australian and New Zealand Journal of Surgery; British Medical Journal, Boletin de la Oficina Sanitaria Panamericana; Bulletin of the World Health Organisation; Bulletin of Endemic Disease (Iraq).

Community Medicine; Central African Journal of Medicine; Giornale Di Medicina Militare; Hellenic Armed Forces Medical Review; Indian Journal of Medical Research; Iranian Journal of Medical Sciences; Iatrika Pepragmena NIMTS; Indian Council of Medical Research.

Journal of the Egyptian Medical Association; Journal of the Oslo City Hospitals; Journal of International Medical Research; Journal of the Faculty of Community Medicine; Journal of the Royal Society of Medicine; Journal of the Australian Medical Association; Journal of the Royal Society of Health; Journal of the American Medical Association; Journal of the British Association for Immediate Care.

Lancet; Medical Digest; Military Medicine; Medecine Et Armees, Military Review; Medecine Tropicale; Medical Journal of Australia; Medicinia Militar; National Defense Medical Journal, Tokyo.

Practitioner; Pakistan Armed Forces Medical Journal; Postgraduate Medical Journal; Quarterly Journal of Medicine.

RAOC Gazette; Royal Engineers Journal; Royal Pioneer; Revue Internationale des Services de Sante; Rivista Sanitara Militara; Revista Portuguesa de Medi cina Militar; Revista de Servicio de Sanidid de las Fuerzas Armandas (Uruguay); Royal Army P Fुy Corps Journal; Revista Cubana de Medicina Tropicaf;을 Revista Medica da Aeronautica do Brasil.

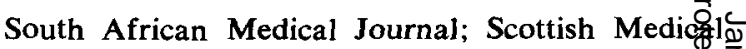
Journal; Stand To - Journal of the Western Froat Organisation; The Gazette (QARANC); Tropical Diseases Bulletin; Transactions and Studies of t傿 College of Physicians of Philadelphia; Ulster Medicgloo Journal; Wehr-Medizinische Monatsschrift.

\section{PUBLICATIONS}

Apartheid and Health - WHO; Cancer in Brazil-_ WHO; City of Durban-Annual Report of the City® Medical Officer of Health; Depressive Disorders in $\Rightarrow$ Different Cultures-WHO; Development over a Halfo Century; Environmental Health Criteria-WHO; Evaluation of certain Food Additives and Contamin ants-WHO; Laboratory Biosafety Manual-WHO; Measuring change in Nutritional Status - WHO; Nuclear Power-Management of High Level Radioactive Waste-WHO; New Approaches to Health Education in Primary Care-WHO; Pest Control: Proceedings of the Royal Society of Medicine; Public Health Papers-WHO; Progress in Standardisation-WHO; Primary Prevention of Essential Hyper 3 tension; Prevention of Liver Cancer - WHO;Ò Primary Health Care of the Chinese Experience- 3 WHO; Salus: Low Cost Rural Health Care ando Health Manpower Training; Statistics in Practice; The Traditional Birth Attendant in Seven CountriesWHO; The Use of Essential Drugs; Technical Report Series - WHO; Traditional Medicine and Healtho Care Coverage-WHO; WHO Chronicle; WHO Ex-N pert Committee on Biological Standardisation; World Health Forum-WHO. 